\title{
Perception, attitude and opinion of the Spanish tourists about the episodes of extreme heat
}

\author{
M. B. Gómez-Martín ${ }^{1}$, X. Armesto-López ${ }^{1}$ \& E. Martínez-Ibarra ${ }^{2}$ \\ ${ }^{I}$ Department of Physical Geography and Regional Geographical \\ Analysis, University of Barcelona, Spain \\ ${ }^{2}$ Inter-University Institute of Geography, University of Alicante, Spain
}

\begin{abstract}
Here we present the perception, attitude, opinion and behaviour of Spanish tourists when faced with an episode of extreme heat, with temperatures similar to those forecast for summers at the end of the $21^{\text {st }}$ century. The study was based on personal questionnaires, 351 of which were issued after a holiday period to university students in their role as tourist-consumers, following the Lexis stratified random sampling method. The results show that, for the geographic area of study, tourists largely perceive the extreme phenomenon as an event that could affect tourism in Spain. However, they also believe that the Spanish tourist sector is capable of devising strategies to mitigate possible negative effects. The attitude and behaviour of the tourists also show their capacity to adapt; they assess the measures introduced by the sector to date in the different destinations, while highlighting some shortcomings. This information should help to fill the current gap regarding knowledge of how tourist-citizens perceive certain extreme episodes and behave when faced with them, which could be highly important given that such episodes may become 'normal phenomena' as a result of climate change. This information may be useful in devising strategies for the adaptation and future sustainability of tourist destinations.

Keywords: tourism, heatwave, climate change, adaptation, Spain.
\end{abstract}

\section{Introduction}

Knowledge of the average global warming affecting the earth's surface in the course of the last century has meant that the phenomenon of climate change has today become one of the main subjects of debate and reference in the context of 
the world economic policies that are to govern the future of the planet in the years to come (Valdés et al. [1]). The importance of tourism as part of the global economy and the undeniable links that this activity has with atmospheric elements make it advisable to look at climate change in all its manifestations: any kind of alteration to current climate patterns in the different regions of the planet will bring about considerable changes in a fair proportion of current tourist sites. The Spanish mainland and islands, the geographical framework for our research, is in this respect one of the areas where predicted changes in climate will generate more significant alterations (Ministry of the Environment [2]).

In the case of Spain, one aspect of future climate predictions which is just as important as changes in the average values for temperature and rainfall is the possible alteration in the intensity and frequency of extreme climate events. What is interesting about this type of analysis is that the impact of alterations in future climate due to changes in climate extremes would generally be more serious than that associated with changes in the average climate (Ministry of the Environment [3]). In this investigation, of the various extreme climate events of interest in our geographic area of study, we will focus our attention on what are known as "heatwaves".

Heatwaves are difficult to specify precisely because there are various meteorological definitions (Giles and Balafoutis [4]) and various methods for limiting an episode of this type (Kalkstein and Valimont [5]). Nevertheless, they are characterized by certain common patterns. They are often defined as extreme events marked by high temperatures which persist for a period of several days (WMO [6]). In short, heatwaves can be restricted to two determining factors recorded in unison: the crossing of a specific thermal threshold, which will determine whether or not a day can be considered hot, and the persistence of this over a certain number of days (Folland et al. [7]). From an atmospheric point of view, heatwaves are associated with mechanisms that operate on a synoptic scale, usually related to stationary or semi-stationary high pressure systems of subtropical origin (Koffi and Koffi [8]).

The damage caused by these types of episode on the physical environment, socio-economic activities and human health are usually considerable, as pointed out in a number of studies (García et al. [9]; Díaz et al. [10]; Martínez et al. [11]). In the case of tourism, it is known that tourist behaviour is influenced by the weather, among other things (Hu and Ritchie [12]; Crouch [13]; Butler [14]; Gómez-Martín [15]; Gómez-Martín and Martínez-Ibarra [16]). The degree of influence is determined by how sensitive a particular type of tourism is to the weather and climate in general and/or to certain atmospheric elements in particular. Hence these types of extreme phenomena can to varying degrees jeopardize tourists' safety, comfort and enjoyment, and can bring about considerable changes - in these tourists' normal behaviour - that may threaten the future of tourist destinations. This is why finding out how tourists perceive and behave with regard to these types of extreme events (which are likely to become more frequent phenomena as a result of climate change) may be useful for developing strategies for the adaptation and future sustainability of tourist destinations. 
Our investigation, through the use of questionnaires, aims to explore public knowledge, perception, attitude and tourist behaviour before, during and after the summer holiday period affected by the episode of extreme heat of 2003. This heatwave can be put forward as an example of what would be a "normal" situation - due to its frequency - during European summers towards the end of the 21 st century, and can serve as a laboratory setting for our study. This episode has turned out to be one of the most significant in mainland Spain for the period 1968-2010 (Martínez-Ibarra [17]). From an analysis of summer 2003 it can be seen that, except for certain places on the coast, practically the whole summer (June, July and August) passed under heatwave conditions, with records for both maximum and minimum temperatures being broken in many weather stations on the mainland and in the Balearic Islands (see Tables 1 and 2). The hottest period of summer 2003 has a duration of approximately 15 days and corresponds to the first fortnight in August (with slight variations depending on area), making it the longest though not the most intense heatwave since records began.

Table 1: Records of absolute maximum temperatures recorded in summer 2003.

\begin{tabular}{|c|c|c|c|}
\hline \multirow{2}{*}{ Weather station } & 2003 & \multicolumn{2}{|c|}{ Previous record } \\
\cline { 2 - 4 } & Temperature $\left({ }^{\circ} \mathrm{C}\right)$ & Temperature $\left({ }^{\circ} \mathrm{C}\right)$ & Year \\
\hline Oviedo & 35.6 & 35.5 & 2000 \\
\hline San Sebastian & 38.6 & 38.2 & 1928 \\
\hline Barcelona & 37.3 & 35.0 & 1948 \\
\hline Girona & 41.2 & 39.0 & 1982 \\
\hline Badajoz & 44.8 & 44.4 & 1995 \\
\hline Huelva & 43.4 & 43.2 & 1946 \\
\hline
\end{tabular}

Source : AEMET [18].

Table 2: $\quad$ Tropical summer nights (minimum temperature equal to or above $\left.20^{\circ} \mathrm{C}\right)$.

\begin{tabular}{|c|c|c|}
\hline Weather station & Average value for the period 1971-2000 & 2003 \\
\hline A Coruña & 0.2 & 2 \\
\hline Albacete & 2.8 & 6 \\
\hline Badajoz & 8.7 & 20 \\
\hline Cordoba & 17.9 & 39 \\
\hline Granada & 7.2 & 10 \\
\hline Ibiza & 54.3 & 83 \\
\hline Madrid & 20.2 & 46 \\
\hline Malaga & 38.0 & 67 \\
\hline Murcia & 28.7 & 60 \\
\hline San Sebastian & 1.4 & 13 \\
\hline Santander & 1.7 & 14 \\
\hline Seville & 29.4 & 57 \\
\hline Tortosa & 36.2 & 67 \\
\hline Valencia & 52.4 & 85 \\
\hline Zamora & 1.8 & 97 \\
\hline Zaragoza & 13.9 & \\
\hline The values for 2003 are the highest in the series except in the cases of Badajoz (22 nights in \\
\hline 1989), Albacete (11 nights in 1994) and Granada (24 nights in 1994)
\end{tabular}

Source : AEMET [19]. 
Next we present the main results of this study, which, through the use of questionnaires, aims to explore the public knowledge, perception and tourist behaviour of Spanish tourists before, during and after the summer holiday period affected by the 2003 heatwave. After this introduction we describe the methodology used, the responses deriving from the test and the initial conclusions of this exploratory study.

\section{Methodology}

This study focuses on domestic Spanish tourism: the importance of these tourist flows for the Spanish economy justify their being the subject of our investigation [20]. Therefore the analysis presented here is based on 351 personal questionnaires administered using Lexis stratified random sampling [21] to Spanish university students from the University of Barcelona (Spain) who went on holiday [22] within Spain during the summer affected by the 2003 heatwave. This is an ex situ investigation in which the questionnaires were administered after the summer holiday period affected by the episode of extreme heat in question (see Table 3).

Table 3: $\quad$ Technical details of the survey.

\begin{tabular}{|c|}
\hline Technical details \\
\hline Methodology: Quantitative; personal questionnaire \\
\hline Size of sample: 351 personal questionnaires \\
\hline Type of sample: Lexis random stratified \\
\hline Sampling error: $\pm 5 \%$ \\
\hline Confidence interval: $95.5 \%(2 \sigma)$ \\
\hline Variance $(\mathrm{p}, \mathrm{q}): \mathrm{p}=50 \% ; \mathrm{q}=50 \%$ \\
\hline Validation systems: random probe $(n=30)$ \\
\hline
\end{tabular}

The questionnaire used, which was semi-structured (with open and closed questions) and in Spanish, aimed to explore the public knowledge, perception, attitude and tourist behaviour that the respondents exhibited before, during and after the summer holidays affected by the episode of extreme heat in 2003. A number of authors have pointed out the usefulness of questionnaires in studying extreme episodes and natural risks (Drabek [23]; Enders [24]; Haynes et al. [25]; Johnston et al. [26]; Rohrmann [27]). Bird [28], for example, states that as tools they are fundamental for acquiring information about the public knowledge and perception of extreme natural events that may be useful for developing procedures and management strategies so as to reduce the vulnerability of a population to the phenomenon in question. Bulmer [29], too, points to the usefulness of questionnaires in obtaining information about past and present behaviour in the face of a particular extreme natural episode, about standards of behaviour in a group, about attitudes, beliefs and reasons for action. Taking all 
this into account, the questions were designed to explore the following aspects of interest in this investigation:

- Public knowledge and perceptions of the individuals, in their role as tourist-consumers, as regards the impact of the target episode of extreme heat on tourist activity.

- Behaviour of the individuals, in their role as tourist-consumers, before the holiday experience affected by the target episode of extreme heat.

- Behaviour of the individuals, in their role as tourist-consumers, during the holiday experience affected by the target episode of extreme heat.

- Perception, attitude and behaviour of the individuals, in their role as tourist-consumers, after the holiday experience affected by the target episode of extreme heat.

\section{Results}

\subsection{Sectors of activity, in the geographic area of the study, affected by the 2003 heatwave}

Being offered specific options, respondents were asked about those sectors of activity in the geographic area of the study that they perceived as being the ones most affected by the 2003 heatwave. The results showed tourism to be in third place with $11.55 \%$, after agriculture $(33.94 \%)$ and the livestock sector $(26.04 \%)$. These were followed by construction $(9.73 \%)$, fishing $(6.89 \%)$, commerce $(5.88 \%)$, the energy sector $(3.04 \%)$ and industry $(2.43 \%)$. Only $0.51 \%$ of respondents thought that no sector of activity was affected by the extreme episode in question.

\subsection{The role of the episode of extreme heat in decision-making during the pre-holiday period}

An interest in looking into the holiday experience as a whole led us to determine three specific moments: the pre-holiday period, the holiday period itself and the post-holiday period. In this sense it is interesting to explore in the context of our study what role the extreme event in question played in decision-making and how information sources were used during the event. Respondents were therefore asked whether this extreme event had the effect of making them modify their holiday plans, the responses showing that only $7.12 \%$ of the respondents altered their initial plans (see Table 4). Replies to the question "How did you modify your initial plans?" mainly indicated that it was by changing destination or postponing the holiday until later in the year.

As far as information is concerned, the respondents stated that during the period before their holidays they had increased their consultation and use of different information sources in order to follow meticulously the evolution, manifestations and recommendations relating to this extreme meteorological event (see Figure 1), along the same lines pointed out in studies by Hamilton and Lau [30], Rutty and Scott [31], Scott et al. [32] and Smith [33]. 
Table 4: $\quad$ The extreme episode's influence on modifying holiday plans.

\begin{tabular}{|l|c|}
\hline \multicolumn{1}{|c|}{ Did the extreme episode influence you to modify your holiday plans? } & $\%$ \\
\hline No & 92.59 \\
\hline Yes, this summer's holiday plans were altered due to the extreme episode & 7.12 \\
\hline Don't know/Doesn't apply & 0.28 \\
\hline
\end{tabular}

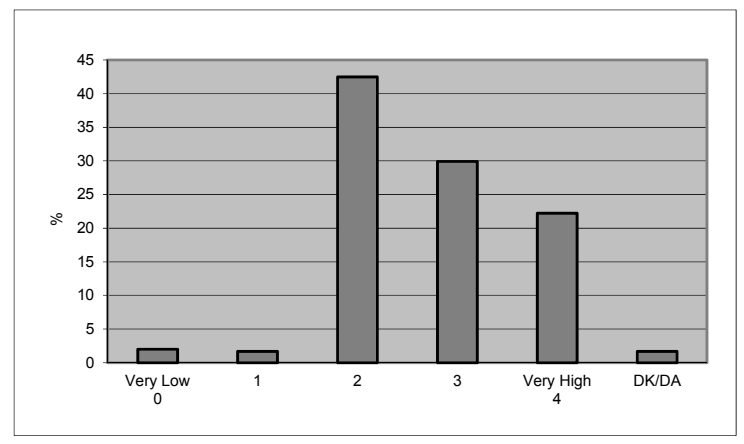

Figure 1: Consultation and use of information sources to obtain information about the extreme episode (pre-holiday period).

Respondents also indicated that the information was of quite an acceptable level as regards appropriateness (see Figure 2), replying to the open question Why? that despite the fact that it occasionally took on a sensationalist tone and was extremely extensive, it was thorough, accurate in its forecasts and above all necessary. In their role as consumer-tourists, the respondents show that they accept alarmist and sensationalist headlines as positive as long as these succeed in making individuals aware of the event's various implications and of the measures to be taken to try to mitigate its effects without having to change destination.

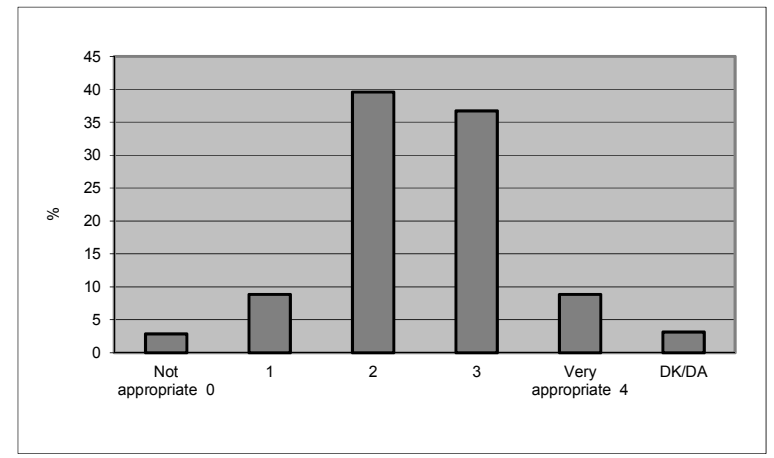

Figure 2: Degree of appropriateness of the information relating to the extreme episode (pre-holiday period). 


\subsection{The impact of the episode of extreme heat during the holiday period}

On asking respondents what effect these conditions of extreme heat had on the way their holidays developed, we obtain a great many replies in the middle category $(55.56 \%)$, although after this it is the categories on the negative side that take on slightly greater importance $(25.93 \%)$ compared to the positive side $(16.52 \%)$ (see Figure 3$)$. It therefore seems that, once in the holiday location, the extreme episode did not generate too many setbacks for the respondents apart from those $25.93 \%$.

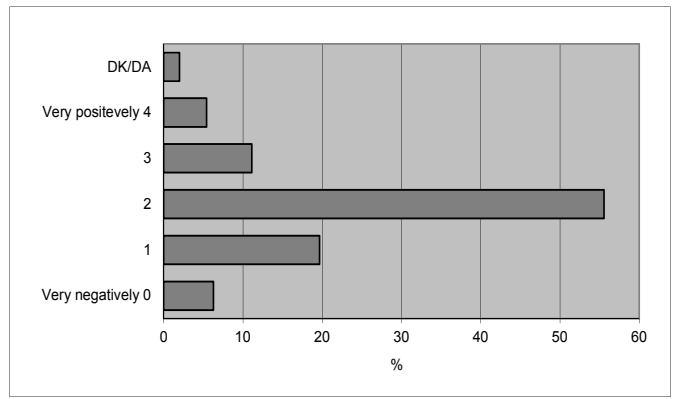

Figure 3: How did the conditions of extreme heat affect the development of your holidays?

When respondents were asked to what extent during the holidays the conditions of extreme heat affected their sensation of enjoyment, comfort and safety, the replies were again situated mainly in the middle categories (see Table 5 ), although it can be observed that the comfort variable obtains a higher impact.

Table 5: During the holidays, how did the conditions of extreme heat affect your feelings of enjoyment, safety and comfort?

\begin{tabular}{|c|c|c|c|c|c|c|}
\hline & $\begin{array}{c}1 \text { Decreased } \\
\text { noticeably }\end{array}$ & 2 & 3 & 4 & $\begin{array}{c}5 \text { Increased } \\
\text { noticeably }\end{array}$ & DK/DA \\
\hline Comfort & $17.09 \%$ & $37.89 \%$ & $33.90 \%$ & $7.12 \%$ & $2.56 \%$ & $1.42 \%$ \\
\hline Safety & $6.84 \%$ & $14.53 \%$ & $69.52 \%$ & $6.27 \%$ & $1.71 \%$ & $1.14 \%$ \\
\hline Enjoyment & $7.69 \%$ & $17.66 \%$ & $49.29 \%$ & $16.24 \%$ & $7.98 \%$ & $1.14 \%$ \\
\hline
\end{tabular}

In answer to the question "What effect did the extreme conditions have as regards more or less time spent on the following activities during your holiday?", the replies indicate that the conditions of extreme heat caused changes to be made in certain activities carried out by the tourists. Hence, according to the correspondents, the use of beaches, swimming pools and water parks increased in comparison to normal summers; the same happened as regards more time spent inside the accommodation and on outdoor and indoor leisure activities. Visits and walks around parks and countryside along with visits to museums and exhibitions remained stable compared to other years, but there was a fall in visits 
to cities, towns and villages and above all in playing outdoor and indoor sports (see Table 6).

Table 6: During the holidays, how did the extreme conditions affect the increase or decrease of time spent on these activities?

\begin{tabular}{|l|c|c|c|c|c|c|}
\hline & $\begin{array}{c}1 \text { Decreased } \\
\text { noticeably }\end{array}$ & 2 & 3 & 4 & $\begin{array}{c}5 \text { Increased } \\
\text { noticeably }\end{array}$ & DK/DA \\
\hline Use of beaches, pools, water parks & $5.41 \%$ & $4.27 \%$ & $27.35 \%$ & $25.07 \%$ & $37.04 \%$ & $0.85 \%$ \\
\hline Visits to museums, exhibitions, etc. & $14.53 \%$ & $13.96 \%$ & $44.73 \%$ & $14.81 \%$ & $11.11 \%$ & $0.85 \%$ \\
\hline Visits to cities, towns, villages, etc. & $12.82 \%$ & $18.23 \%$ & $44.16 \%$ & $15.95 \%$ & $8.55 \%$ & $0.28 \%$ \\
\hline $\begin{array}{l}\text { Visits and walks around parks, } \\
\text { countryside }\end{array}$ & $9.97 \%$ & $19.37 \%$ & $39.03 \%$ & $20.23 \%$ & $10.83 \%$ & $0.57 \%$ \\
\hline $\begin{array}{l}\text { Time spent inside the } \\
\text { accommodation }\end{array}$ & $13.39 \%$ & $13.11 \%$ & $41.88 \%$ & $18.23 \%$ & $12.54 \%$ & $0.85 \%$ \\
\hline Playing outdoor sports & $22.79 \%$ & $23.65 \%$ & $32.48 \%$ & $13.11 \%$ & $7.69 \%$ & $0.28 \%$ \\
\hline Playing indoor sports & $26.50 \%$ & $18.80 \%$ & $39.89 \%$ & $9.12 \%$ & $3.13 \%$ & $2.56 \%$ \\
\hline Outdoor leisure activities & $9.12 \%$ & $12.25 \%$ & $36.75 \%$ & $24.22 \%$ & $16.81 \%$ & $0.85 \%$ \\
\hline Indoor leisure activities & $9.69 \%$ & $12.54 \%$ & $35.33 \%$ & $24.50 \%$ & $17.66 \%$ & $0.28 \%$ \\
\hline
\end{tabular}

Similarly, the tourists also admit to having modified certain everyday habits during their holidays. When asked what everyday habits they had modified during the holidays affected by the 2003 heatwave, $25.53 \%$ responded by saying they had modified - upwards - their water consumption; $17.62 \%$ admitted changing their hours of activity; $14.01 \%$ decreasing the intensity of the activity; $13.41 \%$ increasing energy consumption; $10.91 \%$ changing the type of activity; $10.81 \%$ adapting their diet; $2.90 \%$ increasing spending, with $0.40 \%$ DK/DA. Only $4.40 \%$ state that their habits remain unchanged.

\subsection{Post-holiday assessment and impact on future decision-making}

As to the assessment respondents make of their holidays taking into account the effects of the extreme episode on their tourist experiences and activities, it is striking how positive the results are: $0.85 \%$ opted for an assessment of very bad, $5.13 \%$ bad, $26.78 \%$ normal, $37.32 \%$ good and $28.77 \%$ very good. Possibly the degree to which tourist infrastructures, facilities and services in Spanish destinations were able to adapt to cope with the extreme event has much to do with this, as shown by the replies to the question "To what extent do you think tourist infrastructures, facilities and services were adapted to cope with the extreme episode?" (see Table 7).

Using an open question, respondents were asked about the types of adaptation they had observed in the tourist destinations visited (see Figure 4). The adaptations positively mentioned were: the temperature control of closed spaces by air conditioning, the temperature control of open spaces by evaporative cooling, the increased watering of urban green spaces, the modified scheduling of certain outdoor activities and the extension of opening hours for swimming pools and water parks. Also noted was the importance and intensification of fire prevention campaigns. 
Table 7: To what extent do you think tourist infrastructures, facilities and services were adapted to cope with the extreme episode?

\begin{tabular}{|l|c|}
\hline \multicolumn{1}{|c|}{ Level of adaptation } & $\%$ \\
\hline 0 not adapted & 6.84 \\
\hline 1 little adaptation & 19.66 \\
\hline 2 moderately adapted & 31.91 \\
\hline 3 highly adapted & 25.07 \\
\hline 4 complete adaptation & 14.53 \\
\hline DK/DA & 1.99 \\
\hline
\end{tabular}
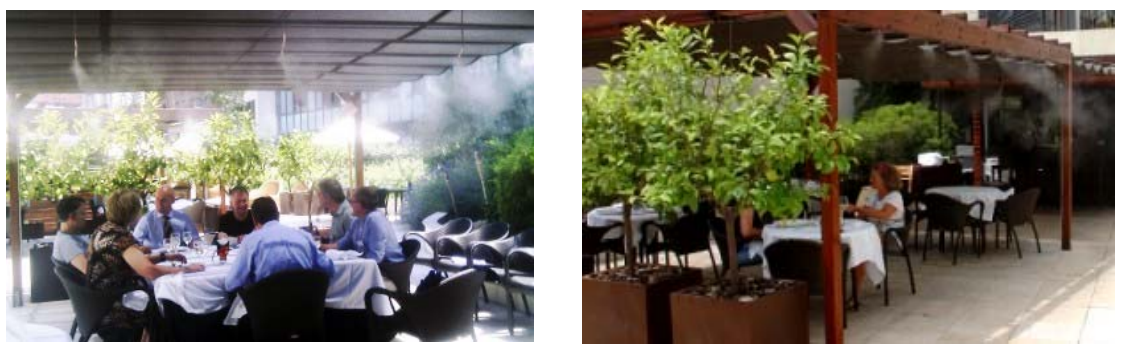

Figure 4: Example of evaporative cooling on a hotel terrace in Barcelona. Source: http://www.hotelescatalonia.com [34]

Respondents were also asked about measures that had not been implemented in the destinations, or had been implemented to a lesser extent. As regards these missed adaptations, respondents mentioned the need to extend permanent awning-covered areas in the historic centres of towns, increase the number of shady areas in gardens in tourist destinations and make free water consumption possible by providing public water fountains. Some respondents who stayed on campsites or in tourist apartments reported the need to create areas of dense shade in camping areas and to install air conditioning in tourist apartments (see Figure 5).

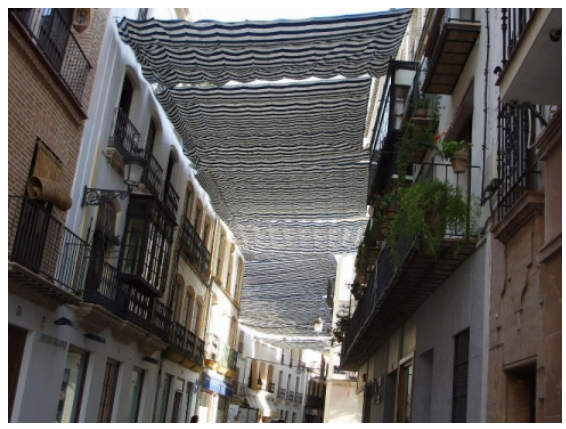

Figure 5: Example of street awnings in the historic centre of Spanish city. 
Finally, respondents were asked whether the atmospheric conditions experienced during this extreme summer made them change their future choice of destination or holiday period. The replies indicate that in $90.8 \%$ of cases they did not. Only $7.2 \%$ say that this extreme summer had an effect on future decisions, while $2 \%$ of respondents gave no opinion either way.

\section{Conclusions}

From a methodological point of view, the questionnaires have proved to be a good tool for obtaining information about the behaviour, attitude and opinion of a particular group in connection with an actually experienced natural episode of extreme heat. Those who completed the questionnaires responded satisfactorily to both the closed and the open questions (the latter receiving lengthy answers), enabling a great deal of information to be obtained.

The respondents see tourism in this geographical area as one of the three sectors most affected by the extreme heatwave episode. They showed a clear awareness of the extent to which the sector is sensitive to atmospheric elements. Despite this, the respondents reported that a wide range of options exists for adapting the tourist environment, meaning that holiday planning was affected less than scheduling, and as a result few people affected by the heatwave during the summer altered their initial holiday plans by changing destination or postponing their holiday until later in the year. Here we have an extreme phenomenon to which our tourist system is highly exposed and highly sensitive, but which, thanks to both spontaneous and planned changes put into effect by various elements of the tourism system, has a low impact capacity. This low impact capacity reduces the vulnerability of our tourist sector to heatwave events. This is in line with the results of other recent investigations which, also based on an analysis of questionnaires, concluded that tourists see heatwaves as the extreme episodes that generate the least negative impact on tourism (Moreno [35]). This shows that there is a need to review the results of certain studies that predicted unfortunate effects on our tourism sector as a result of the increase in high temperatures due to climate change (Bigano et al. [36]; Hamilton et al. [37]; Moreno and Amelung [38]; Scott et al. [39]).

The interviewees state that a wide range of adaptive responses are available in the tourist system, which can be effected by tourists themselves, market agents and operators. The responses suggest that tourists show great flexibility, quickly adapting to the extreme heat by changing their behaviour patterns (e.g., changes in recreational choices, changes in time scheduling, changes in meal times, etc.). Although the other elements of the tourism system are less flexible, respondents recognize and evaluate positively the way these elements have adapted the surroundings. Basically, in order to adapt they have developed mechanisms involving technology (e.g., installing temperature control in closed spaces - air conditioning - and in open spaces - evaporative cooling), administration (e.g., changing the opening hours of certain tourist attractions, changing the scheduling of certain activities) and planning (e.g., increasing watering of urban green spaces, improving and extending planted areas, improving and extending 
awning-covered areas, developing and intensifying fire prevention campaigns). It should be pointed out that these last examples were those which, according to respondents, most need to be improved in our tourism system.

As in previous studies (Hamilton and Lau [40]; Rutty and Scott [41]; Scott et al. [42] and Smith [43]) the respondents said that they needed information to enable them to track the evolution of the extreme weather event and to follow recommendations. They also considered that the information was appropriate; although on occasions it took on a sensationalist character and was very extensive, it was thorough, accurate in its forecasts and above all necessary. In their role as consumer-tourists, respondents have shown that they accept alarmist and sensationalist headlines as positive if they heighten awareness of the event's various implications and of the measures to be taken to try to offset its effects without having to change destination. Our results for Spanish domestic tourism contrast with those obtained by other authors for the tourism originating in the countries of central and northern Europe with the Mediterranean as destination (Rutty and Scott [44]). In this case the harmful role that alarmist information can play in the consumer-tourist's decision-making is clear, especially when the holiday has not been booked or paid for.

Judging from our survey (based on an analysis of behaviour with regard to an actual experience), the Spanish tourist is seen to have the flexibility to adapt to high-temperature episodes as long as the Spanish tourism system implements the necessary mechanisms for adapting to circumstances at the same time. Therefore these types of extreme event do not appear to present a threat to our domestic tourism. Investigation still needs to be carried out into how foreign tourists who had Spain as a destination behaved when faced with the same event and, more especially, what the results would be if the surveys were carried out according to what type of tourism was involved at the time of the event.

\section{Acknowledgement}

This study was conducted within the framework of a Plan Nacional de $I+D+I$ research projects sponsored by Spain's Ministerio de Ciencia e Innovación, reference number CSO2008-01346 and CSO2011-23404.

\section{References}

[1] Valdés, L., Gómez-Martín, M.B. \& Moreno, A., El turismo y el cambio climático en Asturias. Evidencias y efectos potenciales. Boletín de la Asociación de Geógrafos Españoles, 57, pp.243-265, 2011.

[2] Ministry of Environment, Evaluación preliminar de los impactos en España por efecto del cambio climático, Min. de Medio Ambiente: Madrid, 2005.

[3] Ministry of Environment, Evaluación preliminar de los impactos en España por efecto del cambio climático, Min. de Medio Ambiente: Madrid, 2005. 
[4] Giles, B.D. \& Balafoutis, C.J., The Greek heat waves of 1987 and 1988. International Journal of Climatology, 10, pp.505-517, 1990.

[5] Kalkstein, L.S. \& Valimont, K.M., An evaluation of summer discomfort in the United States using a relative climatological index. Bulletin of American Meteorological Society, 67, pp.842-848, 1986.

[6] WMO, Meeting of the Joint CCI/CLIVAR task group on climate indices. World Climate Data and Monitoring Programme, WCDMP No. 37, WMOTD No. 930, WMO: Bracknell, 1999.

[7] Folland, C.K., Miller, C., Bader, D., Crowe, M., Jones, P., Plummer, N., Richman, M., Parker, D.E., Rogers, J. \& Scholefield, P., Breakout group C: Temperature indices for climate extremes. Climatic Change, 4, pp.31-43, 1999.

[8] Koffi, B. \& Koffi, E., Heat waves across Europe by the end of the 21st century: multiregional climate simulations. Climate Research, 36, pp.153168, 2008.

[9] García, R., Díaz, J., Trigo, R.M. \& Hernández, E., Extreme summer temperatures in Iberia: health impacts and associated synoptic conditions. Annales Geophysicae, 23, pp.239-251, 2005.

[10] Díaz, J., García, R., Trigo, R.M., Linares, C., Valente, M.A., De Miguel, J.M. \& Hernández, E., The impact of the summer 2003 heat wave in Iberia: how should we measure it? International Journal of Biometeorology, 50, pp.159-166, 2006.

[11] Martínez, F., Simón-Soria, F. \& López-Abente, G., Valoración del impacto de la ola de calor del verano de 2003 sobre la mortalidad. Gaceta Sanitaria, 18, pp.250-258, 2004.

[12] Hu, Y. \& Ritchie, J., Measuring destination attractiveness: a contextual approach. Journal of Travel Research, 32(20), pp.25-34, 1993.

[13] Crouch, G.I., The study of international tourism demand: A review of practice. Journal of Travel Research, 33, pp.41-54, 1994.

[14] Butler, R., Seasonality in tourism: Issues and implications. Seasonality in Tourism, eds. T. Baum \& S. Lundtorp, Pergamon: London, pp.5-22, 2001.

[15] Gómez-Martín, M.B., Weather, Climate and Tourism. A Geographical Perspective. Annals of Tourism Research, 32(3), pp.571-591, 2005.

[16] Gómez-Martín, M.B. \& Martínez-Ibarra, E., Behaviour of tourism demand and atmospheric parameters: non-intrusive observation techniques. Climate Research doi:10.3354/cr01068, 2011 in press.

[17] Martínez-Ibarra, E., The use of webcams images to determine touristclimate aptitude: favourable weather types for sun and beach tourism on the Alicante coast (Spain). International Journal of Biometeorology, 55, pp.373-385, 2011.

[18] AEMET, Resumen de extremos climatológicos en España, Ministerio de Medio Ambiente y Medio Rural y Marino: Madrid, 2007.

[19] AEMET, Resumen de extremos climatológicos en España, Ministerio de Medio Ambiente y Medio Rural y Marino: Madrid, 2007.

[20] De acuerdo con las estadísticas de FAMILITUR (IET, 2010), en 2010 los españoles realizaron 162,2 millones de viajes, la mayor parte de los cuales 
$(148,6)$ tuvieron como destino el territorio estatal. IET, Movimientos turísticos de los españoles (FAMILITUR). Instituto de Estudios Turísticos: Madrid, 2010.

[21] En el muestreo aleatorio estratificado de Lexis se muestrea un estrato de la población (en este caso, estudiantes universitarios españoles mayores de 18 años que practicaron turismo en el territorio español durante el verano de 2003) en representación de todos (españoles mayores de 18 años que practicaron turismo en el territorio español durante el verano de 2003).

[22] Señalar que el $28,60 \%$ de los encuestados practicó como modalidad principal durante el verano referenciado turismo de sol y playa; el 3,79\%, turismo náutico; el 24,05\% turismo de naturaleza; el $27,46 \%$ turismo cultural; el 5,68\%, turismo de deportes de aventura y el $10,42 \%$ otras modalidades turísticas.

[23] Drabek, T.E., Human System Responses to Disaster: An Inventory of Sociological Findings, Springer-Verlag: New York, 1986.

[24] Enders, J., Measuring community awareness and preparedness for emergencies. Australian Journal of Emergency Management, 16, pp.52-58, 2001.

[25] Haynes, K., Barclay, J. \& Pidgeon, N., Whose reality counts? Factors affecting the perception of volcanic risk. Journal of Volcanology and Geothermal Research, 172, pp.259-272, 2008.

[26] Johnston, D., Paton, D., Crawford, G.L., Ronan, K., Houghton, B. and Burgelt, P., Measuring Tsunami Preparedness in Coastal Washington, US. Natural Hazards, 35, pp.173-184, 2005.

[27] Rohrmann, B., Risk attitude scales: concepts and questionnaires. Project Report, 21. University of Melbourne, Australia, 2004.

[28] Bird, D.K., The use of questionnaires for acquiring information on public perception of natural hazards and risk mitigation. A review of current knowledge and practice. Natural Hazards and Earth System Sciences, 9, pp.1307-1325, 2009.

[29] Bulmer, M., Questionnaires, Sage Benchmarks in Social Science Research Methods series, Sage Publications: London, 2004.

[30] Hamilton, J.M. \& Lau, M.A., The role of climate information in tourist destination choice decision-making. Tourism and global environmental change, eds. S. Gössling \& C.M. Hall, Routledge: London, pp.229-250, 2005.

[31] Rutty, M. \& Scott, D., Will the Mediterranean become "too hot" for tourism?. A Reassessment. Tourism Planning and Development, 7(3), pp.267-281, 2010.

[32] Scott, D., Lemieux, C.J. \& Malone, L., Climate services to support sustainable tourism and adaptation to climate change. Climate Research, 47, pp.111-122, 2011.

[33] Smith, K., The effect of weather conditions on the public demand for meteorological information. Journal of Climatology, 1, pp.381-393, 1981.

[34] Hoteles Catalonia, www.hotelescatalonia.com. 
[35] Moreno, A., Mediterranean Tourism and Climate (Change): A Surrey-based study. Tourism and Hospitality Planning and Development, 7(3), pp.253$265,2010$.

[36] Bigano, A., Hamilton, J. \& Tol, R.S.J., The Impact of Climate on Holiday Destination Choice. Climatic Change, 76, pp.389-406, 2006.

[37] Hamilton, J., Maddison, D. \& Tol, R., Effects of climate change on international tourism. Climate Research, 29, pp.245-254, 2005.

[38] Moreno, A. \& Amelung, B., Climate change and tourist comfort on Europe's beaches in summer: a reassessment. Coastal Management, 37, pp.550-568, 2009.

[39] Scott, D., Gossling, S. \& de Freitas, C.R., Preferred climates for tourism: case studies from Canada, New Zealand and Sweden. Climate Research, 38(1), pp.61-73, 2008.

[40] Hamilton, J.M. \& Lau, M.A., The role of climate information in tourist destination choice decision-making. Tourism and global environmental change, eds. S. Gössling \& C.M. Hall, Routledge: London, pp.229-250, 2005.

[41] Rutty, M. \& Scott, D., Will the Mediterranean become "too hot" for tourism?. A Reassessment. Tourism Planning and Development, 7(3), pp.267-281, 2010.

[42] Scott, D., Lemieux, C.J. \& Malone, L., Climate services to support sustainable tourism and adaptation to climate change. Climate Research, 47, pp.111-122, 2011.

[43] Smith, K., The effect of weather conditions on the public demand for meteorological information. Journal of Climatology, 1, pp.381-393, 1981.

[44] Rutty, M. \& Scott, D., Will the Mediterranean become "too hot" for tourism? A Reassessment. Tourism Planning and Development, 7(3), pp.267-281, 2010. 